\title{
Analisis Kerentanan Pencemaran Air Tanah di Kota Batu Menggunakan Analisis Multikriteria Spasial dengan Indeks DRASTIC
}

\author{
Luhur Akbar Devianto ${ }^{1}$ \\ Fakultas Teknologi Pertanian, Universitas Brawijaya, Malang, Indonesia
}

Novia Lusiana

Fakultas Teknologi Pertanian, Universitas Brawijaya, Malang, Indonesia

\section{Fatwa Ramdani}

Fakultas Teknologi Pertanian, Universitas Brawijaya, Malang, Indonesia

Artikel Masuk : 27 November 2018

Artikel Diterima : 26 Juli 2019

Tersedia Online : 31 Agustus 2019

\begin{abstract}
Abstrak: Air tanah dan air permukaan merupakan salah satu sumber air bersih yang perlu dikelola dengan baik. Salah satu pemanfaatan air tanah dan mata air di Kota Batu sebagai bagian dari hulu Daerah Aliran Sungai (DAS) Brantas adalah menjadi sumber air bersih di Kota Batu dan Kota Malang. Oleh karena itu, apabila air tanah serta air permukaan terkontaminasi air limbah akan menimbulkan permasalahan ketersediaan air bersih bagi masyarakat di hulu DAS Brantas yang meliputi Kota Batu, Kota Malang, dan Kabupaten Malang. Kualitas air tanah yang terdegradasi ditandai dengan meningkatnya konsentrasi nitrat, total dissolve solid, dan bakteri coli. Penelitian ini bertujuan untuk menganalisis tingkat kerentanan pencemaran air tanah dengan analisis multikriteria spasial menggunakan indeks DRASTIC. Indeks DRASTIC merupakan analisis multikriteria berdasarkan parameter yang digunakan antara lain kedalaman permukaan air tanah, curah hujan, jenis akuifer, tekstur tanah, kemiringan lahan, jenis zona tak jenuh, dan konduktivitas hidraulis akuifer. Hasil penelitian menunjukkan bahwa Kota Batu memiliki tingkat kerentanan rendah sebesar 86,93\% dan sedang sebesar $13,07 \%$. Faktor dominan yang berpengaruh dalam tingkat kerentanan setiap wilayah berbeda-beda. Faktor paling dominan adalah tinggi permukaan air tanah yang bervariasi serta kemiringan lahan, dan kondisi geologi. Meskipun penerapan metode DRASTIC tidak dapat menunjukkan secara spesifik tingkat pencemaran terhadap berbagai jenis pencemar dan perlu data yang detail, metode ini dapat membantu dalam perencanaan wilayah terutama untuk menentukan wilayah yang tingkat pencemaran air tanahnya tinggi, manajemen sumber daya air, hingga upaya konservasi air tanah.
\end{abstract}

Kata Kunci: air tanah; indeks DRASTIC; Kota Batu; analisis multikriteria spasial

Abstract: Groundwater and surface water are important sources of clean water which require an effective management. The use of groundwater and spring as exemplified by Batu City

\footnotetext{
${ }^{1}$ Korespondensi Penulis: Fakultas Teknologi Pertanian, Universitas Brawijaya, Malang, Indonesia email: 1uhur.devianto@gmail.com
} 


\section{Analisis Kerentanan Pencemaran Air Tanah di Kota Batu...}

case - as part of Brantas watershed upstream - serves as raw water as well as clean water source for Batu City and Malang City population. Contamination of surface water and groundwater affects clean water supply as indicated by increasing nitrate, TDS, and E. Coli concentration. The study aims to analyze the vulnerability level of groundwater contamination by using spatial multicriteria analysis with DRASTIC index. The DRASTIC index is measured from some parameters such as surface water depth to water table, net recharge, aquifer media, soil media, topography, impact of vadose zone, and hydraulic conductivity to evaluate groundwater vulnerability. The results show that Batu City performs low vulnerability $(86.93 \%)$ and medium vulnerability $(13.07 \%)$ levels. The dominant factors affecting the level of vulnerability are groundwater levels, slope, and geological conditions across regions. Even though the DRASTIC modelling cannot specify the contamination levels of the different sources, this method is useful to identifying high-level contaminated land uses, managing water resources, and conserving groundwater sources.

Keywords: Batu City; DRASTIC index; groundwater vulnerability; spatial multicriteria analysis

\section{Pendahuluan}

Air limbah domestik dan air limbah hasil aktivitas manusia merupakan salah satu sumber permasalahan lingkungan di kawasan permukiman di Indonesia. Berdasarkan karakteristik dan beban pencemarnya, air limbah domestik dikategorikan menjadi greywater seperti air bekas cucian di dapur, laundry, mandi dan blackwater berupa lumpur tinja hasil buangan manusia (Jeppesen, 1996). Pengelolaan limbah domestik dilaksanakan dengan dua metode yaitu sistem terpusat (off-site) dan sistem setempat (on-site). Pada pengelolaan sistem terpusat, limbah domestik dialirkan dari sumber air limbah baik dari permukiman ataupun fasilitas umum menuju Instalasi Pengolahan Air Limbah (IPAL) menggunakan jaringan perpipaan. Sistem setempat dilakukan melalui pengelolaan lumpur tinja menggunakan tangki septik yang secara berkala antara 2-5 tahun dilakukan penyedotan yang kemudian diolah di Instalasi Pengolahan Lumpur Tinja (USAID, 2016).

Berdasarkan rencana pembangunan nasional, target pelayanan air limbah pada tahun 2019 harus sudah mencapai 100\%. Padahal pada tahun 2015 pelayanan di Indonesia hanya sekitar 62,44\% (BAPPENAS, 2015). Dalam rangka mencapai sasaran tersebut, 85\% pembangunan infrastruktur air limbah lebih diarahkan dengan penanganan sistem setempat. Sisanya $15 \%$ dikembangkan melalui sistem terpusat secara bertahap di wilayah dengan kepadatan tinggi dan wilayah yang strategis.

Pengelolaan limbah dengan sistem pengelolaan air limbah sistem setempat berdampak pada masalah pengurasan dan pembuangan secara periodik (Shivendra \& Ramaraju, 2015). Selain itu, pengelolaan seperti ini memungkinkan terjadinya kebocoran tangki septik, yang secara sederhana ditandai dengan lamanya tangki septik tidak dikuras. Tangki septik yang jarang dikuras dapat menyebabkan terjadinya rembesan/kebocoran yang akan mencemari air tanah.

Pencemaran ini dipengaruhi oleh kondisi hidrogeologi, jenis tanah, kedalaman muka air tanah, dan jarak sumur dengan lokasi sanitasi setempat. Dampaknya terjadi peningkatan konsentrasi kontaminan baik kimia maupun bakteriologis seperti nitrat, total dissolve solid (TDS), total coliform, faecal coliform yang melebihi standar kesehatan (Banerjee, Singh, Singh, Prasad, \& Rangarajan, 2011; Lawrence et al., 2001; Lewis, Foster, \& Drasar, 1980; Rao, Sekhar, \& Rao, 2013). Otago Regional Council (2015) menunjukkan kepadatan tangki septik di wilayah permukiman juga memengaruhi tingkat pencemaran air tanah.

Air tanah dan air permukaan merupakan salah satu sumber air bersih yang saat ini perlu dikelola dengan baik. Salah satu pemanfaatan air tanah dan mata air di Hulu DAS Brantas adalah sebagai sumber air baku Perusahaan Daerah Air Minum (PDAM) di Kota Batu dan Kota Malang yang berpenduduk lebih dari 1 juta jiwa. Penelitian Widiatmono, 
Anugroho, Nurlaelih, Sulianto, \& Lusiana (2017) menunjukkan bahwa kualitas air sungai Brantas yang berada di Kota Batu memiliki indeks pencemaran air termasuk kriteria agak tercemar pada dua belas titik. Penelitian lainnya di Kota Batu oleh Taryana (2015) menunjukkan bahwa konsentrasi nitrit dan nitrat air yang berasal dari mata air di dekat daerah padat penduduk memiliki konsentrasi yang lebih tinggi akibat aktivitas manusia. Air tanah dan air permukaan yang terkontaminasi limbah akan menimbulkan permasalahan ketersediaan air bersih, sehingga diperlukan analisis kerentanan pencemaran air tanah di Kota Batu.

Metode analisis kerentanan (vulnerability) pencemaran air tanah salah satunya dapat dilakukan dengan menggunakan analisis multikriteria dan indeks DRASTIC (Depth, Recharge, Aquifer, Soil, Topography, Impact of Vadose Zone, Conductivity) berbasis spasial atau Sistem Informasi Geografis (SIG). Model analisis menggunakan indeks DRASTIC diperkenalkan oleh Aller, Lehr, Petty, \& Bennett (1987) untuk mengevaluasi pencemaran air tanah di Amerika, yang kemudian banyak digunakan untuk mengevaluasi kerentanan air tanah maupun kerentanan pencemaran air tanah di Jepang, India, dan Tunisia (Babiker, Mohamed, Hiyama, \& Kato, 2005; Rahman, 2008; Zghibi, Merzougui, Chenini, Ergaieg, Zouhri, \& Tarhouni, 2016).

SIG mentransformasi input data spasial menjadi output suatu keputusan dengan prosedur yang melibatkan data geografis, pengambilan keputusan, pengolahan data, dan preferensi terhadap rencana pengambilan keputusan. Faktor yang penting dalam analisis ini adalah kemampuan SIG dalam akuisisi data, penyimpanan, manipulasi dan analisis data, serta kemampuan analisis multikriteria dalam mengombinasikan analisis data geografis dengan preferensi pengambilan keputusan (Malczewski, 2004). Beberapa penelitian menggunakan SIG dan analisis multikriteria spasial menghasilkan alternatif penyelesaian permasalahan sederhana seperti pemilihan lokasi imbuhan air tanah (Devianto, Suwarman, Rohman, \& Iqbal, 2017) hingga analisis yang kompleks seperti pengelolaan sampah di Saharawi, Aljazair (Garfi, Tondelli, \& Bonoli, 2009), pemilihan lokasi TPA landfill (Sumathi, Natesan, \& Sarkar, 2008), pemilihan Tempat Pembuangan Akhir Bahan Berbahaya dan Beracun (TPA B3) (Sharifi, Hadidi, Vessali, Mosstafakhani, \& Taheri, 2009), infrastruktur pemanenan air hujan (Singhai, Das, Kadam, Shukla, Bundela, ., \& Kalashetty, 2019; Tiwari, Goyal, \& Sarkar, 2018), hingga analisis kerentanan air tanah pada suatu DAS (Kovarik, Beynen, \& Niedzielski, 2017) dan pada akuifer di kawasan pantai.

Penelitian mengenai kerentanan pencemaran air tanah karena limbah domestik di Kota Batu hingga saat ini belum pernah dilakukan. Pada penelitian ini analisis multikriteria spasial menggunakan indeks DRASTIC dilakukan untuk mengetahui tingkat kerentanan pencemaran air tanah tersebut. Penelitian ini bertujuan untuk menganalisis tingkat kerentanan pencemaran air tanah dengan analisis multikriteria spasial menggunakan indeks DRASTIC.

\section{Metode Penelitian}

Penelitian dilakukan dengan tahapan studi pustaka, identifikasi masalah, penentuan lokasi penelitian, dan pengambilan sampel kedalaman air tanah. Analisis kerentanan pencemaran air tanah dengan analisis multikriteria spasial dilakukan dengan menggunakan perangkat lunak ArcGIS dan QGIS dengan model DRASTIC (Aller et al., 1987), yaitu model kombinasi DRASTIC yang terdiri dari variabel depth of water table/kedalaman muka air tanah (D), recharge/curah hujan (R), aquifer media/jenis akuifer (A), soil media/tekstur tanah $(\mathrm{S})$, topography/kemiringan lahan $(\mathrm{T})$, impact of vadose zone/jenis zona tak jenuh (I), conductivity hydraulic/konduktivitas hidraulis (C). Peta-peta tematik seperti peta kedalaman air tanah, peta curah hujan, peta jenis akuifer, peta tekstur tanah, peta kemiringan lahan, dan peta jenis zona tak jenuh yang dibuat menggunakan perangkat lunak 


\section{Analisis Kerentanan Pencemaran Air Tanah di Kota Batu...}

ArcGIS dan QGIS berdasarkan data lapangan dan data sekunder. Kedua perangkat lunak ini juga digunakan untuk menghasilkan peta tingkat kerentanan pencemaran air tanah menggunakan overlay tools (tumpang susun). Kerangka kerja penelitian dilaksanakan menurut Gambar 1. Pembobotan parameter kerentanan serta kelas dan nilai setiap parameter dapat dilihat pada Tabel 1 dan Tabel 2.

Parameter tersebut kemudian dihitung untuk mendapatkan indeks DRASTIC dengan formula (1):

$$
\text { Kerentanan }=D_{R} D_{W}+R_{R} R_{W}+A_{R} A_{W}+S_{R} S_{W}+T_{R} T_{W}+I_{R} I_{W}+C_{R} C_{W}
$$

dengan (R) adalah nilai untuk masing-masing parameter dan (W) adalah bobot untuk masing-masing parameter.

Tabel 1. Pembobotan Parameter Kerentanan DRASTIC

\begin{tabular}{cclc}
\hline No & & \multicolumn{1}{c}{ Parameter } & Bobot \\
\hline 1 & D & Depth to water table / kedalaman muka air tanah & 5 \\
2 & $\mathrm{R}$ & Recharge / curah hujan & 4 \\
3 & $\mathrm{~A}$ & Aquifer media / jenis akuifer & 3 \\
4 & $\mathrm{~S}$ & Soil media / tekstur tanah & 2 \\
5 & $\mathrm{~T}$ & Topography / kemiringan lahan & 1 \\
6 & $\mathrm{I}$ & Impact of vadose zone media / jenis zona tak jenuh & 5 \\
7 & $\mathrm{C}$ & Conductivity hydraulic / konduktivitas hidraulis akuifer & 3 \\
\hline
\end{tabular}

Sumber: Aller et al., 1987; Zghibi et al., 2016

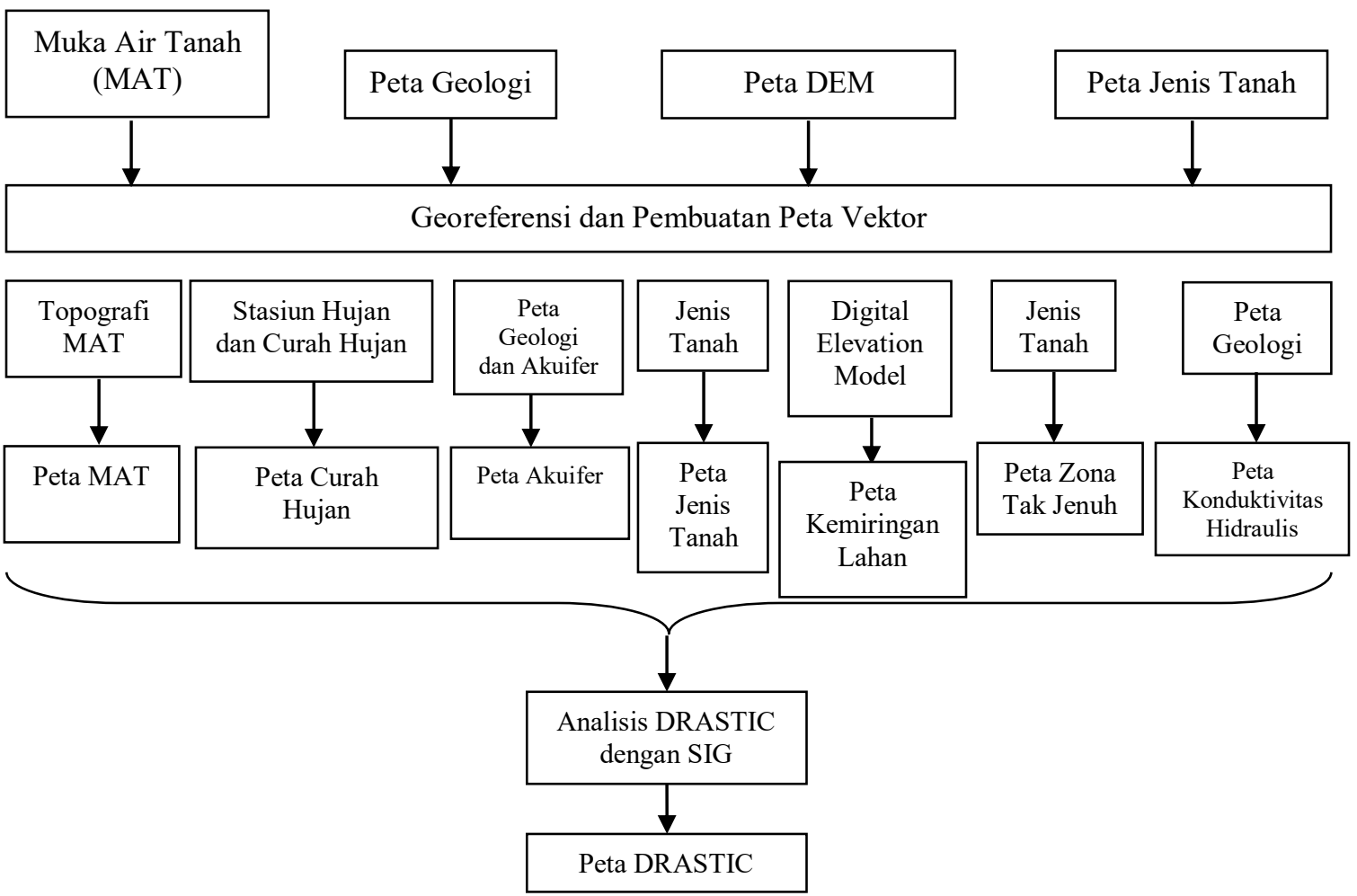

Sumber: Zghibi et al, 2016

Gambar 1. Kerangka Kerja Penelitian 
Luhur Akbar Devianto, Novia Lusiana, Fatwa Ramdani 94

Tabel 2. Kelas dan Nilai Parameter Kerentanan DRASTIC

\begin{tabular}{|c|c|c|c|c|c|c|c|c|c|c|c|c|c|}
\hline \multicolumn{2}{|c|}{$\begin{array}{l}\text { Kedalaman Air } \\
\text { Tanah (m) }\end{array}$} & \multicolumn{2}{|c|}{$\begin{array}{l}\text { Curah Hujan } \\
(\mathrm{mm})\end{array}$} & \multicolumn{2}{|l|}{ Jenis Akuifer } & \multicolumn{2}{|c|}{ Tekstur Tanah } & \multicolumn{2}{|c|}{$\begin{array}{c}\text { Kemiringan } \\
\text { Lahan }(\%)\end{array}$} & \multicolumn{2}{|c|}{ Jenis Zona Tak Jenuh } & \multicolumn{2}{|c|}{$\begin{array}{c}\text { Konduktivitas } \\
\text { Hidraulis (m/hari) }\end{array}$} \\
\hline Kelas & Nilai & Kelas & Nilai & Kelas & Nilai & Kelas & Nilai & Kelas & Nilai & Kelas & Nilai & Kelas & Nilai \\
\hline $0-3$ & 10 & $200-300$ & 9 & Serpih masif & 2 & Kerikil & 10 & $0-2$ & 10 & Lapisan batas & 1 & $0,04-4,1$ & 1 \\
\hline $3-4,5$ & 9 & $150-200$ & 8 & metamorf / beku & 3 & Pasir & 9 & $2-6$ & 9 & Lempung / Lanau & 3 & $4,1-12,3$ & 2 \\
\hline $4,5-9$ & 7 & $120-150$ & 6 & Lapukan metamorf/beku & 4 & Gambut & 8 & $6-12$ & 5 & Serpih & 3 & $12,3-28,7$ & 4 \\
\hline $9-15$ & 5 & $100-120$ & 5 & Glacial till & 5 & Agregat Lempung & 7 & $12-18$ & 3 & Batu gamping & 3 & $28,8-41$ & 6 \\
\hline $15-22$ & 3 & $80-100$ & 3 & $\begin{array}{l}\text { Batu pasir, batu gamping, } \\
\text { dan serpih }\end{array}$ & 6 & Lempung pasiran & 6 & $>18$ & 1 & Batu pasir & 6 & $41-82$ & 8 \\
\hline $22-30$ & 2 & $60-80$ & 2 & Batu pasir masif & 6 & Lempung & 5 & & & $\begin{array}{l}\text { Pasir dan kerikil dan } \\
\text { lanauan }\end{array}$ & 6 & $>82$ & 10 \\
\hline \multirow[t]{4}{*}{$>30$} & 1 & & & $\begin{array}{l}\text { Batu gamping masif, pasir, } \\
\text { kerikil }\end{array}$ & 8 & Lempung lanauan & 4 & & & Pasir dan kerikil & 8 & & \\
\hline & & & & Basal & 9 & Lempung liat & 3 & & & Basal & 9 & & \\
\hline & & & & Batu gamping karst & 10 & Campuran & 2 & & & Batu gamping karst & 10 & & \\
\hline & & & & & & Lempung nonagregat & 1 & & & & & & \\
\hline \multicolumn{2}{|c|}{ Bobot 5} & \multicolumn{2}{|c|}{ Bobot 4} & \multicolumn{2}{|l|}{ Bobot 3} & Bobot 2 & & \multicolumn{2}{|c|}{ Bobot 1} & Bobot 5 & & \multicolumn{2}{|c|}{ Bobot 3} \\
\hline
\end{tabular}

Sumber: Saatsaz, Sulaiman, Eslamian, \& Mohammadi, 2011 


\section{Hasil dan Pembahasan}

\section{Kedalaman Permukaan Air Tanah}

Kedalaman air tanah merupakan salah satu faktor penting yang menunjukkan ketebalan lapisan yang dilalui oleh air untuk mengalami infiltrasi hingga zona akuifer jenuh (Rahman, 2008). Kedalaman permukaan air tanah diketahui dari hasil pengukuran sumur penduduk yang tersebar di seluruh kecamatan Kota Batu, yaitu Kecamatan Junrejo, Kecamatan Batu, dan Kecamatan Bumiaji, dengan kedalaman 13,8 m hingga $>30 \mathrm{~m}$. Berdasarkan pengukuran dibuat peta muka air tanah yang tersaji pada Gambar 2 yang sebelumnya ditentukan kelas parameter dan dihitung bobotnya pada Tabel 3.

Tabel 3. Kelas dan Nilai Parameter Muka Air Tanah

\begin{tabular}{ccc}
\hline Kelas (m) & Nilai & Bobot \\
\hline $9-15$ & 5 & 25 \\
$15-22$ & 3 & 15 \\
$22-30$ & 2 & 10 \\
$>30$ & 1 & 5 \\
\hline \multicolumn{2}{l}{ Sumber: Analisis Penulis, 2018 }
\end{tabular}

\section{Curah Hujan}

Parameter curah hujan ditentukan dengan menggunakan data curah hujan di Kota Batu yang diperoleh dari Badan Meteorologi, Klimatologi dan Geofisika (BMKG). Rata-rata curah hujan di Kota Batu tahun 2013-2016 sebesar 155,2 mm/bulan termasuk dalam kategori curah hujan yang tinggi (Gambar 3), dan bernilai 8 (Tabel 4). Tingginya curah hujan memengaruhi tingkat perpindahan kontaminan yang mudah larut berpindah menuju air tanah bebas sehingga menyebabkan pencemaran air tanah.

Tabel 4. Kelas dan Nilai Parameter Curah Hujan

\begin{tabular}{ccc}
\hline Kelas $(\mathbf{m})$ & Nilai & Bobot \\
\hline $150-200$ & 8 & 32 \\
\hline Sumber: Analisis & Penulis, 2018
\end{tabular}

\section{Jenis Akuifer}

Akuifer merupakan formasi batuan yang dapat menyimpan sejumlah air. Akuifer tanah dangkal berada hingga kedalaman $50 \mathrm{~m}$ dari permukaan tanah. Akumulasi pencemar ke dalam akuifer bergantung pada jenis media akuifer. Semakin besar ukuran butir media akuifer, maka semakin besar potensi pencemaran akuifer. Data jenis akuifer merupakan hasil tumpang susun peta hidrogeologi (lembar kediri) di Kota Batu (Iman, Riawan, Setiawan, \& Abdurahman, 2017) serta peta geologi lembar malang sehingga diketahui litologi penyusun batuan. Peta jenis akuifer dapat dilihat pada Gambar 4. Kota Batu terdiri dari akuifer dengan jenis produktivitas kecil (warna kuning pada peta), sedang (warna hijau pada peta), dan tinggi (warna cyan pada peta) dengan penyebaran beragam. Akuifer dengan produktivitas sedang-tinggi mampu mempercepat penyebaran kontaminan di air tanah (Sugianti, Mulyadi, \& Maria, 2016). Nilai dan bobot parameter akuifer dapat dilihat pada Tabel 5. 


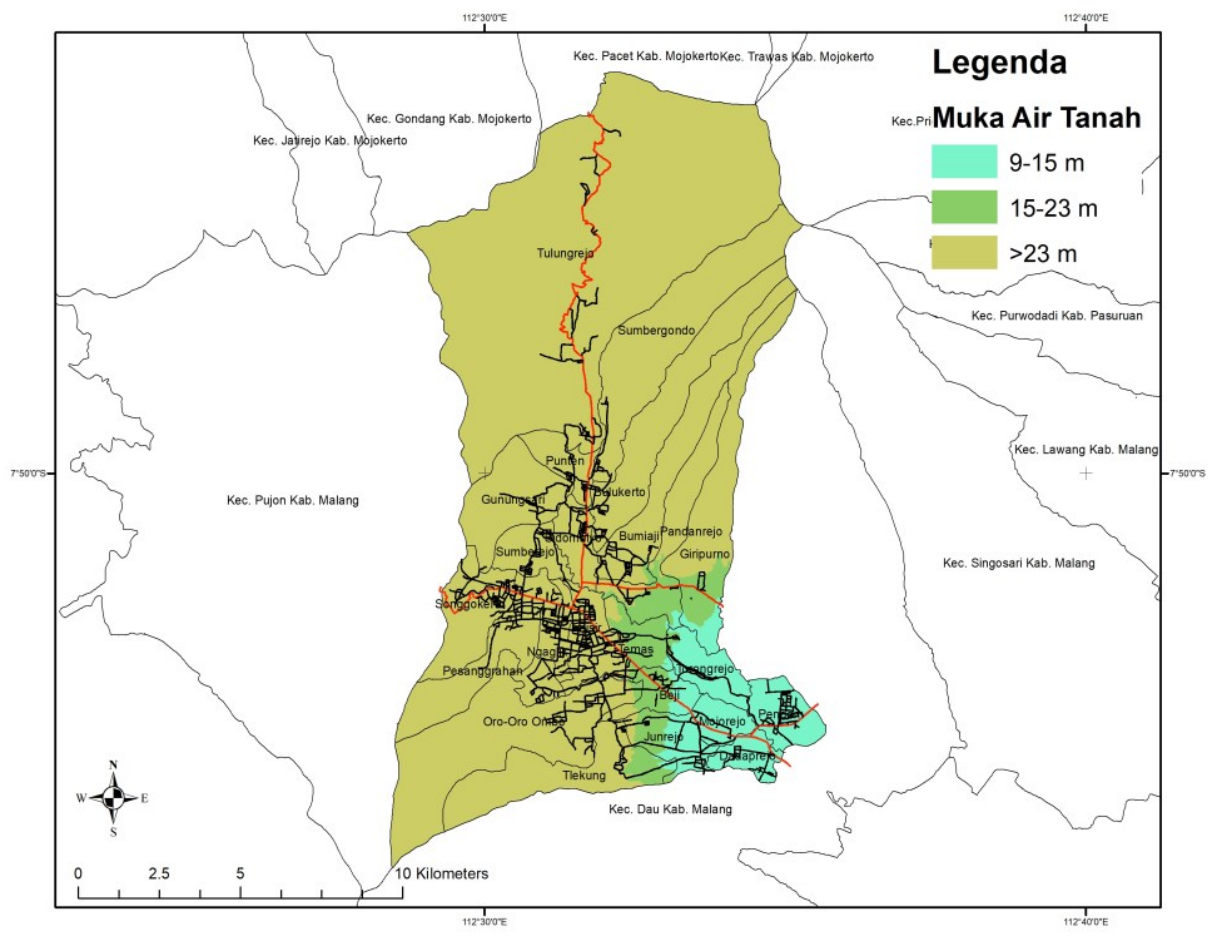

Sumber: Analisis Penulis, 2018

Gambar 2. Peta Penyebaran Permukaan Air Tanah di Kota Batu

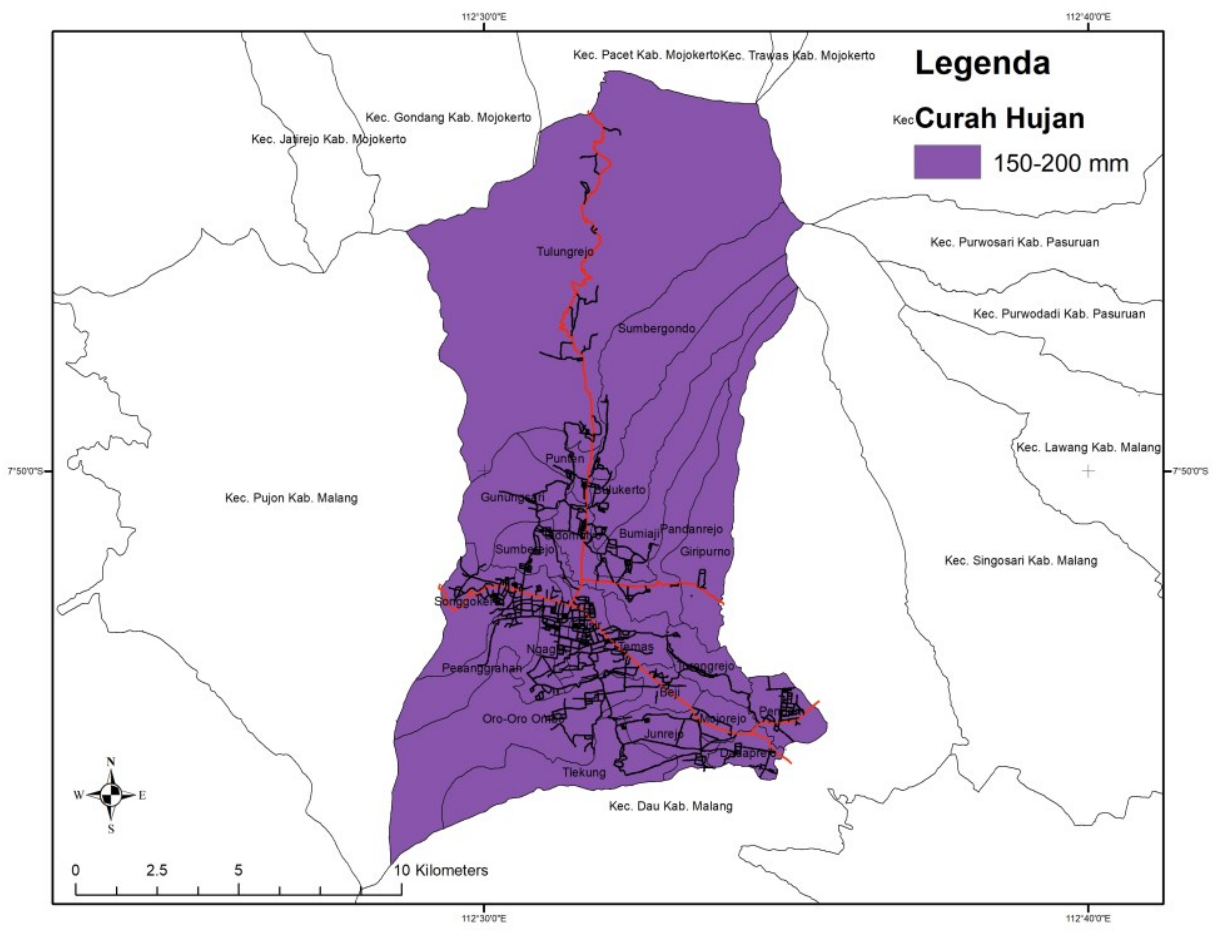

Sumber: Analisis Penulis, 2018

Gambar 3. Peta Curah Hujan di Kota Batu 
Tabel 5. Kelas dan Nilai Parameter Akuifer

\begin{tabular}{llcc}
\hline \multicolumn{1}{c}{ Jenis Akuifer } & \multicolumn{1}{c}{ Kelas } & Nilai & Bobot \\
\hline Akuifer produktif kecil, setempat berarti & Breksi, Tufan & 6 & 18 \\
Celahan dan ruang antar butir, debit $<$ 51/d & Breksi, Tufan & 6 & 18 \\
Celahan, ruang antar butir, produktif sedang-tinggi & Pasir & 8 & 24 \\
\hline
\end{tabular}

Sumber: Analisis Penulis, 2018

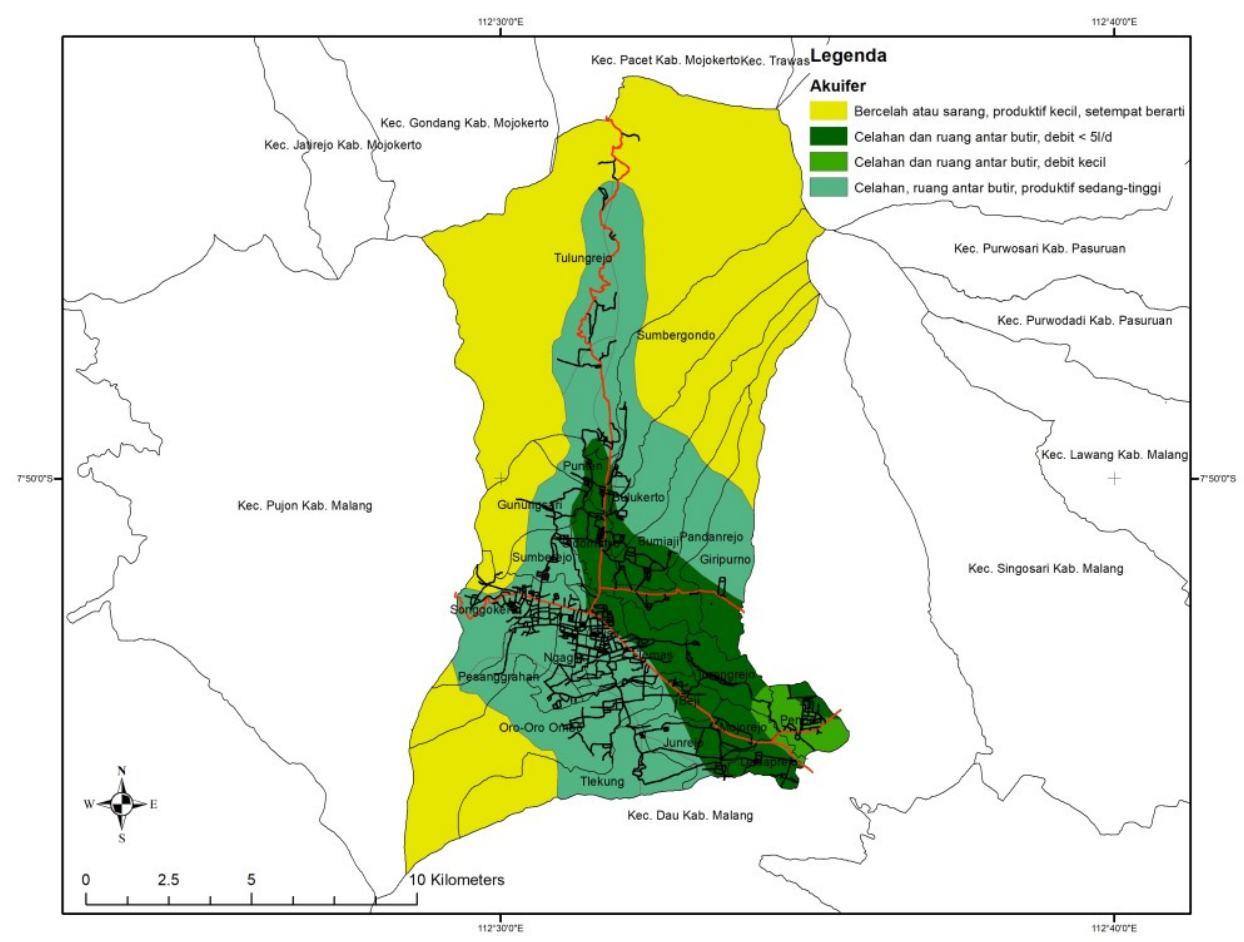

Sumber: Analisis Penulis, 2018

Gambar 4. Peta Jenis Akuifer di Kota Batu

\section{Tekstur Tanah}

Karakteristik tekstur tanah memengaruhi kemampuan infiltrasi air tanah, potensi dispersi, dan penyisihan kontaminan. Tekstur tanah jenis tanah liat, gambut, dan lanau mampu mengurangi permeabilitas dan mencegah migrasi kontaminan dengan proses fisika-kimia seperti absorpsi, penukaran ion, oksidasi, dan biodegradasi (Rahman, 2008). Peta jenis tanah diperoleh dari Bappeda Kota Batu dalam dokumen Kajian Lingkungan Hidup Strategis (KLHS) Kota Batu serta pengamatan di lapangan. Kota Batu memiliki tekstur tanah yang dominan adalah lempung lanauan, sedangkan di beberapa lokasi bertekstur lempung yang relatif lebih mudah dilalui kontaminan. Tekstur tanah pasir memiliki kerentanan lebih tinggi karena daya resap air yang lebih cepat dibanding lainya (Sugianti et al, 2016). Peta tekstur tanah di Kota Batu dapat dilihat pada Gambar 5, dengan nilai dan bobot kriteria tekstur tanah sesuai Tabel 6 . 
Tabel 6. Kelas dan Nilai Parameter Tekstur Tanah

\begin{tabular}{lcc}
\hline \multicolumn{1}{c}{ Kelas } & Nilai & Bobot \\
\hline Lempung & 5 & 10 \\
Lempung lanauan & 4 & 8 \\
\hline Sumber: Analisis Penulis, 2018 &
\end{tabular}

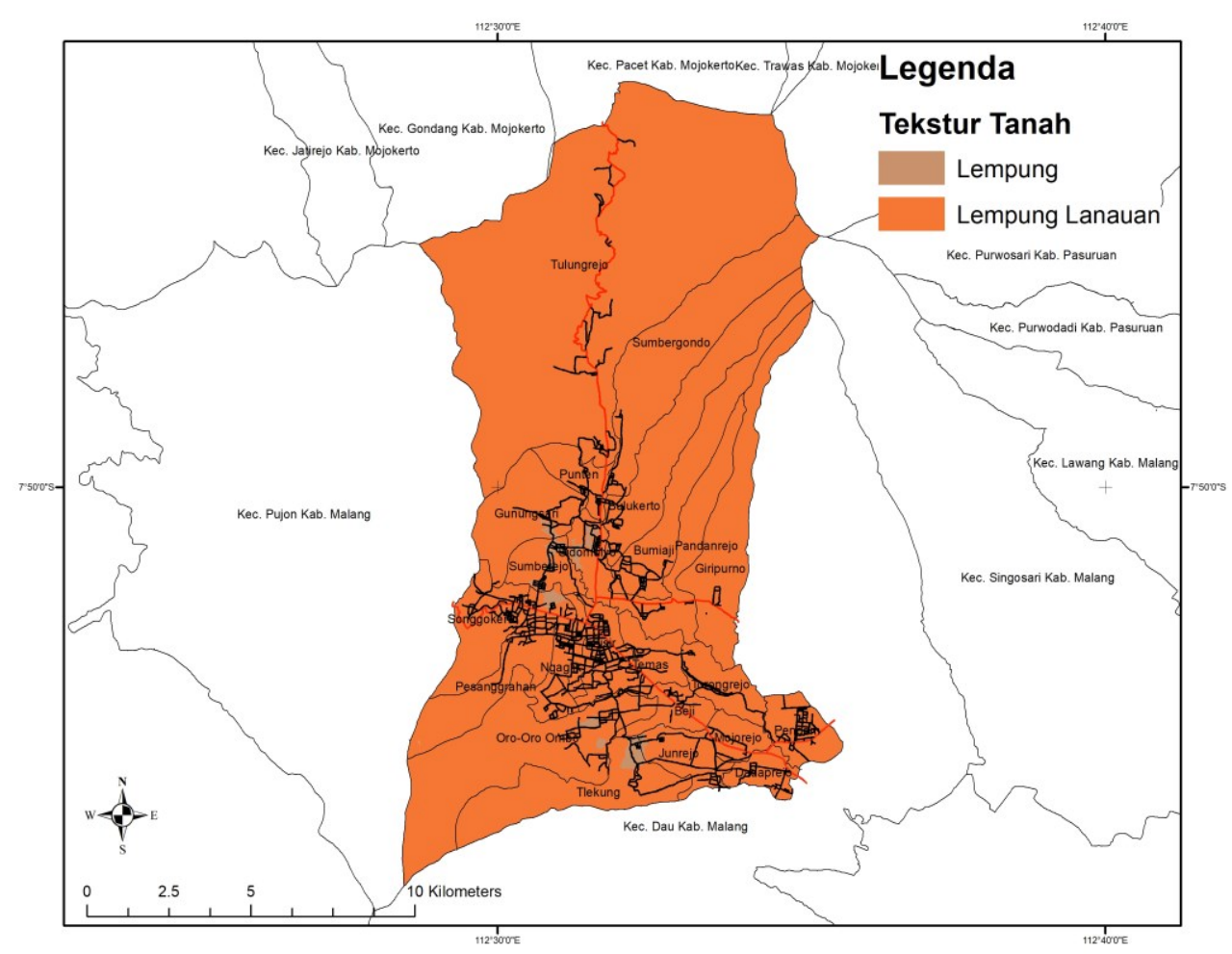

Sumber: Analisis Penulis, 2018

\section{Gambar 5. Peta Tekstur Tanah di Kota Batu}

\section{Kemiringan Lahan}

Parameter kemiringan lahan diperoleh dari pengolahan data Advanced Land Observing Satellite (ALOS) digital surface model (DSM) yang diperoleh dari Japan Aerospace Exploration Agency (JAXA) dengan resolusi $30 \mathrm{~m}$ menjadi peta kemiringan yang diolah menggunakan QGIS. Wilayah dengan kemiringan lahan yang landai cenderung untuk menahan air dan meningkatkan infiltrasi sehingga pergerakan kontaminan ke akuifer lebih tinggi. Sebaliknya, pada kemiringan curam akan menghasilkan limpasan/run-off yang besar, sehingga air tanah tidak mudah terkontaminasi (Rahman, 2008). Wilayah studi memiliki kemiringan yang bervariasi mulai dari lereng datar-landai hingga curam yang tersaji pada Gambar 6. Nilai dan bobot parameter kemiringan lahan sesuai kelasnya dapat dilihat pada Tabel 7. 
Tabel 7. Kelas dan Nilai Parameter Kemiringan Lahan

\begin{tabular}{ccc}
\hline Kelas & Nilai & Bobot \\
\hline $0-2$ & 10 & 10 \\
$2-6$ & 9 & 9 \\
$6-12$ & 5 & 5 \\
$12-18$ & 3 & 3 \\
$>18$ & 1 & 1 \\
\hline
\end{tabular}

Sumber: Analisis Penulis, 2018

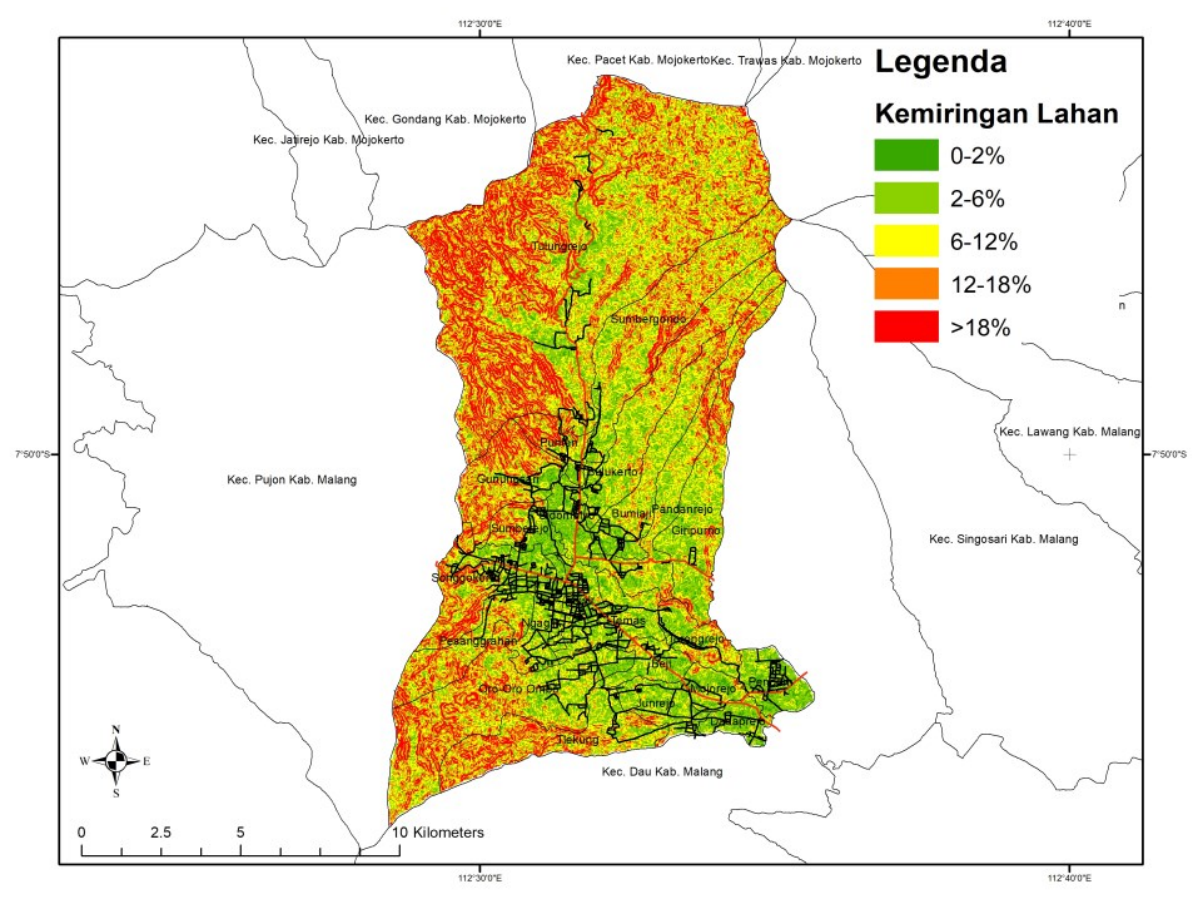

Sumber: Analisis Penulis, 2018

\section{Gambar 6. Peta Kemiringan Lahan di Kota Batu}

\section{Zona Tak Jenuh}

Zona tak jenuh diperoleh dari peta tekstur tanah dengan ukuran butir tanah diasumsikan sebagai lapisan permukaan. Parameter ini sangat berpengaruh dalam mobilitas pencemar. Ukuran butir tanah yang lebih besar dan kondisi tanah yang porous akan meningkatkan pergerakan kontaminan ke dalam akuifer. Peta zona tak jenuh di Kota Batu ditunjukkan pada Gambar 7 dengan nilai dan bobot parameter ini berdasarkan kelasnya ditunjukkan oleh Tabel 8.

Tabel 8. Kelas dan Nilai Parameter Zona Tak Jenuh

\begin{tabular}{lcc}
\hline \multicolumn{1}{c}{ Kelas } & Nilai & Bobot \\
\hline Lempung & 3 & 15 \\
Lempung lanauan & 3 & 15 \\
\hline Sumber: Analisis Penulis, 2018 &
\end{tabular}




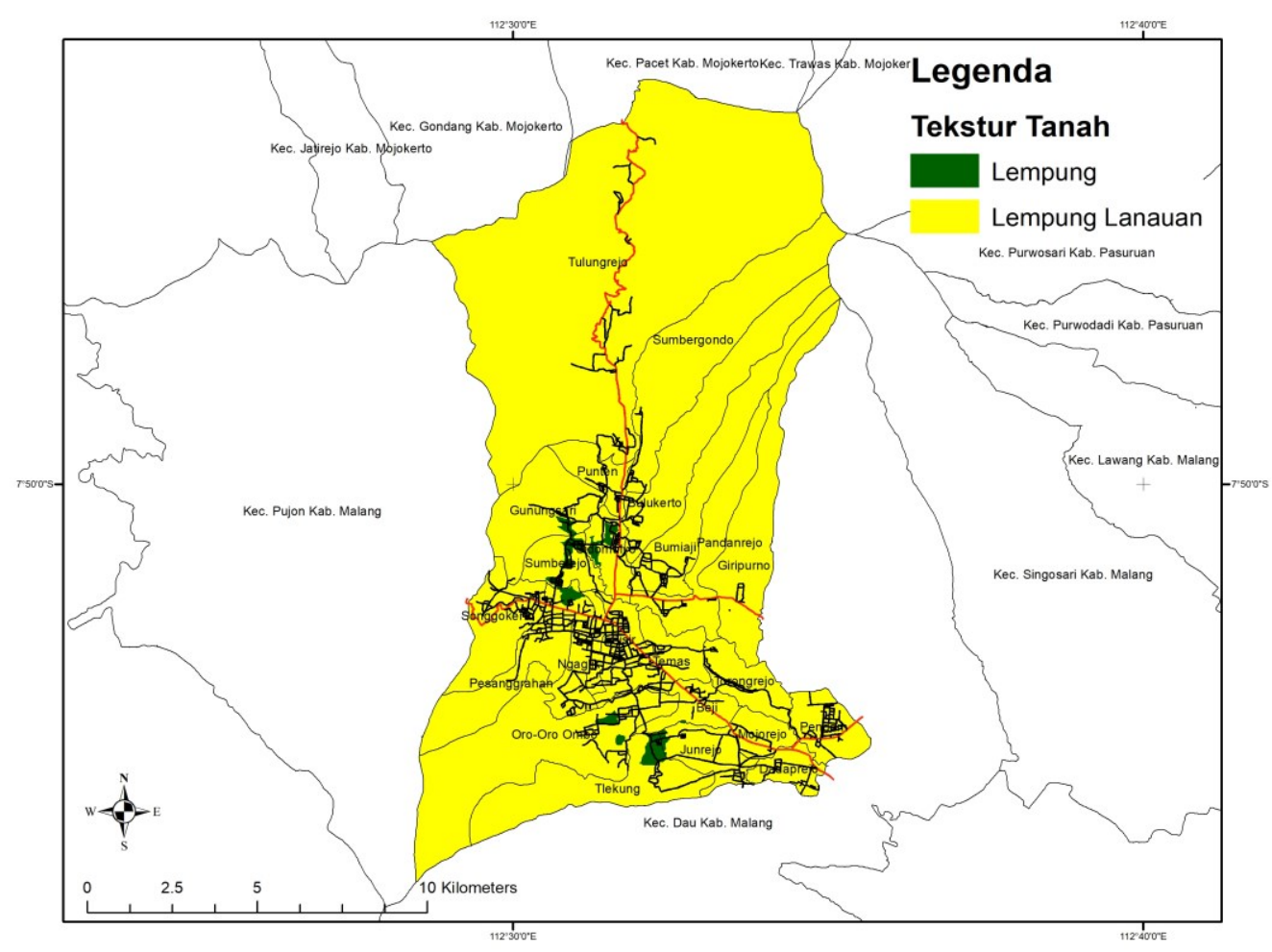

Sumber: Analisis Penulis, 2018

\section{Gambar 7. Peta Zona Tak Jenuh di Kota Batu}

\section{Konduktivitas Hidraulis}

Konduktivitas hidraulis tanah $(\mathrm{K})$ sangat berkaitan dengan porositas dan distribusi ukuran butir tanah yang menentukan dalam keberlanjutan air bawah tanah pada suatu wilayah (Hutasoit, 2009). Nilai konduktivitas hidraulis diambil pada literatur Maria (2008) dan Sugianti et al. (2016) yang memiliki karakteristik sama. Peta konduktivitas hidraulis di Kota Batu dapat dilihat pada Gambar 8, dengan nilai serta bobot parameter ini tersaji pada Tabel 9.

\section{Potensi Kerentanan Pencemaran Air Tanah dengan Metode DRASTIC}

Potensi kerentanan dihitung dengan penjumlahan bobot DRASTIC menjadi indeks DRASTIC yang menunjukkan tingkat kerentanan. Berdasarkan klasifikasi yang dikemukaan Zghibi et al. (2016), indeks kerentanan DRASTIC dibagi menjadi empat tingkat kerentanan yaitu kerentanan rendah (1-100), kerentanan sedang (101-140), kerentanan tinggi (141$200)$, dan kerentanan sangat tinggi (>200). Hasil analisis kerentanan pencemaran air tanah di Kota Batu dengan melakukan tumpang susun (overlay) seluruh peta tematik menggunakan QGIS yang menghasilkan dua tingkat kerentanan yaitu kerentanan rendah $(86,93 \%)$ dan kerentanan sedang (13,07\%) sebagaimana disajikan pada Gambar 9. 


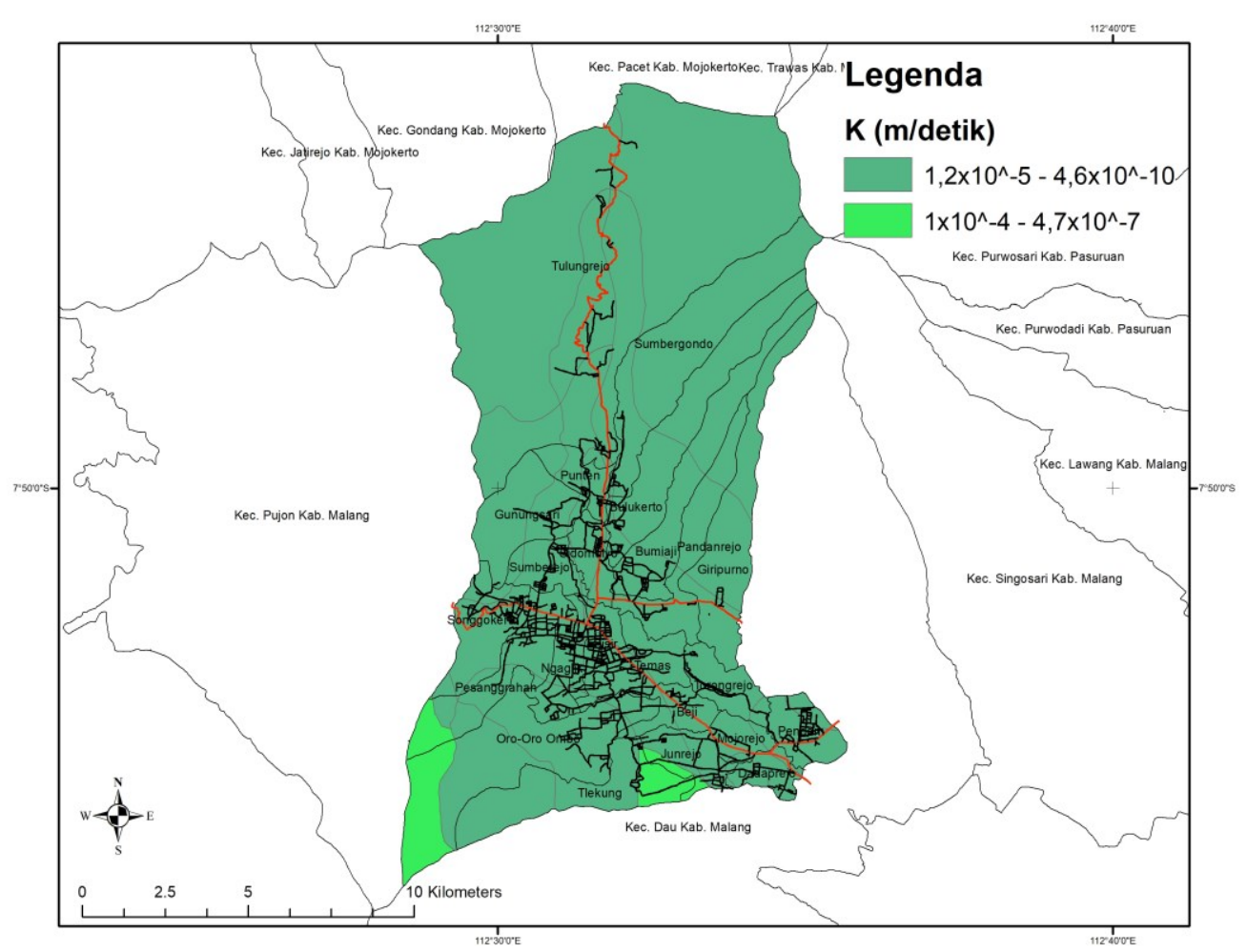

Sumber: Analisis Penulis, 2018

Gambar 8. Peta Konduktivitas Hidraulis di Kota Batu

Tabel 9. Kelas dan Nilai Parameter Zona Tak Jenuh

\begin{tabular}{lccc}
\hline \multicolumn{1}{c}{ Kelas } & $\begin{array}{c}\text { Konduktivitas } \\
(\mathbf{m} / \mathbf{s})\end{array}$ & Nilai & Bobot \\
\hline Breksi gunungapi, breksi tuf, lava, tuf dan aglomerat. & $1,2 \times 10^{-5}-4,6 \times 10^{-10}$ & 2 & 6 \\
Breksi gunungapi, lava, breksi tufan dan tuf & $1,2 \times 10^{-5}-4,6 \times 10^{-10}$ & 2 & 6 \\
Breksi gunungapi, breksi tuf, tuf dan lava & $1,2 \times 10^{-5}-4,6 \times 10^{-10}$ & 2 & 6 \\
$\begin{array}{l}\text { Batupasir tufan, batulempung tufan, batupasir gampingan, } \\
\text { konglomerat, lempung dan tuf }\end{array}$ & $1 \times 10^{-4}-4,7 \times 10^{-7}$ & 2 & 6 \\
Breksi gunungapi, lava, tuf, breksi tufan, aglomerat dan & $1,2 \times 10^{-5}-4,6 \times 10^{-10}$ & 2 & 6 \\
lahar. & $1,2 \times 10^{-5}-4,6 \times 10^{-10}$ & 2 & 6 \\
Breksi gunungapi, breksi tuf, lava, tuf dan aglomerat & &
\end{tabular}

Sumber: Maria, 2008; Sugianti et al., 2016 


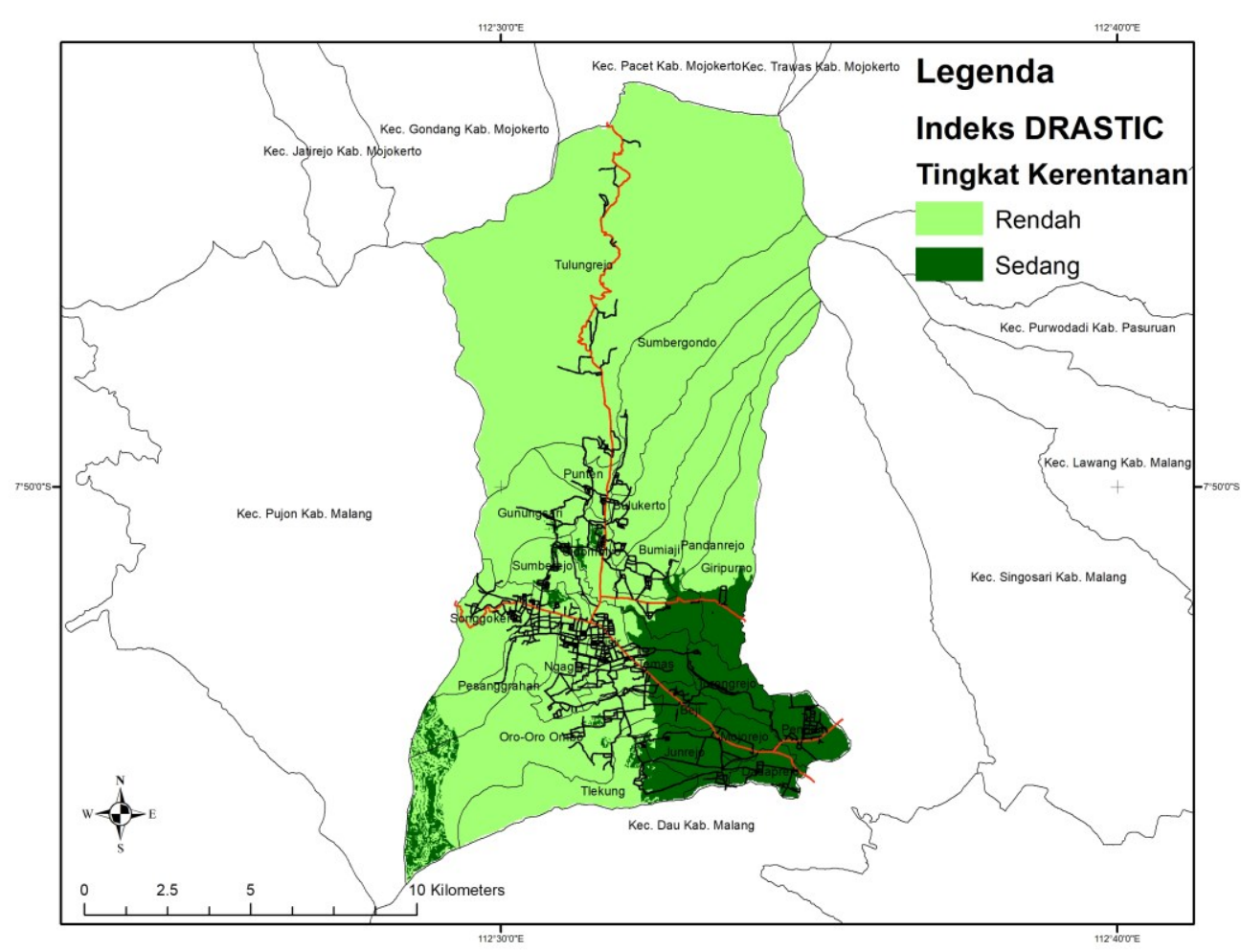

Sumber: Analisis Penulis, 2018

\section{Gambar 9. Peta Kerentanan Pencemaran Air Tanah Indeks Metode DRASTIC di Kota Batu}

\section{Kesimpulan}

Penelitian menunjukkan bahwa tingkat kerentanan pencemaran air tanah di Kota Batu dengan indeks DRASTIC menunjukkan tingkat kerentanan pencemaran yang rendah dan sedang. Faktor dominan yang berpengaruh dalam tingkat kerentanan pada masingmasing wilayah berbeda-beda. Beberapa faktor paling dominan yaitu tinggi permukaan air tanah yang bervariasi serta kemiringan lahan, kondisi geologi dan jenis akuifer. Meskipun penerapan metode DRASTIC tidak dapat menunjukkan secara spesifik tingkat pencemaran terhadap berbagai jenis polutan dan perlu data yang detail, metode ini dapat membantu dalam perencanaan wilayah dalam menentukan wilayah yang memiliki tingkat pencemaran air tanah yang tinggi hingga manajemen dan upaya konservasi air tanah. Salah satu contohnya dalam menentukan zona prioritas pencegahan dan pengendalian pencemaran lingkungan berdasarkan tingkat kerentanan pencemaran air tanah.

\section{Ucapan Terima Kasih}

Penulis mengucapkan terima kasih kepada Ketua Lembaga Penelitian dan Pengabdian Masyarakat (LPPM) Universitas Brawijaya atas fasilitasi dalam pendanaan penelitian ini melalui skema Hibah Peneliti Pemula Universitas Brawijaya melalui dana Penerimaan Negara Bukan Pajak (PNBP) Universitas Brawijaya sesuai dengan Daftar Isian Pelaksanaan Anggaran (DIPA) Universitas Brawijaya Nomor DIPA-042.01.2.400919/2018. 


\section{Daftar Pustaka}

Aller, L., Lehr, J. H., Petty, R., \& Bennett, T. (1987). Drastic: A standardized system to evaluate groundwater pollution potential using hydrogeologic setting. Journal of Geological Society of India, 29(1). Retrieved from http://www.geosocindia.org/index.php/jgsi/article/view/73340.

Babiker, I. S., Mohamed, M. A. A., Hiyama, T., \& Kato, K. (2005). A GIS-based DRASTIC model for assessing aquifer vulnerability in Kakamigahara Heights, Gifu Prefecture, central Japan. Science of the Total Environment, 345(1-3), 127-140. doi:10.1016/j.scitotenv.2004.11.005.

Badan Perencanaan dan Pembangunan Nasional (BAPPENAS). (2015). Agenda nasional pembangunan air minum dan sanitasi 2015-2019. Jakarta.

Banerjee, P., Singh, V. S., Singh, A., Prasad, R. K., \& Rangarajan, R. (2011). Hydrochemical analysis to evaluate the seawater ingress in a small coral island of India. Environmental Monitoring and Assessment, 184(6), 3929-3942. doi:10.1007/s10661-011-2234-0.

Devianto, L. A., Suwarman, R., Rohman, A., \& Iqbal, R. (2017). Determination of retention basin and infiltration well zone for groundwater recharge using GIS-based approach: Case study: Bantaeng regency, South Sulawesi, Indonesia. In 2017 International Symposium on Geoinformatics (ISyG). IEEE Xplore. doi:10.1109/ISYG.2017.8280678.

Garfi, M., Tondelli, S., \& Bonoli, A. (2009). Multi-criteria decision analysis for waste management in Saharawi refugee camps. Waste Management, 29(10), 2729-2739. doi:10.1016/j.wasman.2009.05.019.

Hutasoit, L. M. (2009). Kondisi permukaan air tanah dengan dan tanpa peresapan buatan di daerah Bandung: Hasil simulasi numerik. Indonesian Journal on Geoscience, 4(3), 177-188. Retrieved from https://www.researchgate.net/publication/281021785_Kondisi_Permukaan_Air_Tanah_dengan_dan_t anpa_peresapan_buatan_di_daerah_Bandung_Hasil_Simulasi_Numerik.

Iman, M. I., Riawan, E., Setiawan, B., \& Abdurahman, O. (2017). Air tanah untuk adaptasi perubahan iklim di Malang, Jawa Timur: Penilaian risiko penurunan ketersediaan air. RISET Geologi Dan Pertambangan, 271), 47-64. doi:10.14203/risetgeotam2017.V27.438.

Jeppesen, B. (1996). Domestic greywater re-use: australia's challenge for the future. Desalination, 106(1-3), 311-315. doi:10.1016/0011-9164(96)00124-5.

Kovarik, J. L., Beynen, P. E. van, \& Niedzielski, M. A. (2017). Groundwater vulnerability mapping for a subcatchment of the Rio La Venta watershed, Chiapas, Mexico. Environmental Earth Sciences, 76(23), 1-11. doi:10.1007/s12665-017-7113-8.

Lawrence, A. R., Macdonald, D. M. J., Howard, A. G., Barrett, M. H., Pedley, S., Ahmed, K. M., \& Nalubega, M. (2001). Guidelines for assessing the risk to groundwater from on-site sanitation.

Lewis, W. J., Foster, S. S. D., \& Drasar, B. S. (1980). The risk of groundwater pollution by on-site sanitation in developing countries: A literature review. Switzerland: The International Reference Centre for Waste Disposal.

Malczewski, J. (2004). GIS-based land-use suitability analysis: a critical overview. Progress in Planning, 62(1), 3-65. doi:10.1016/j.progress.2003.09.002.

Maria, R. (2008). Hidrogeologi dan potensi resapan air tanah Sub Das Cikapundung bagian tengah. RISET Geologi Dan Pertambangan, 18(2), 21-30. doi:10.14203/risetgeotam2008.v18.13.

Otago Regional Council. (2015). Groundwater contamination risk, septic tank density and distribution within Otago. Dunedin: Otago Regional Council.

Rahman, A. (2008). A GIS based DRASTIC model for assessing groundwater vulnerability in shallow aquifer in Aligarh, India. Applied Geography, 28(1), 32-53. doi:10.1016/j.apgeog.2007.07.008.

Rao, S. M., Sekhar, M., \& Rao, P. R. (2013). Impact of pit-toilet leachate on groundwater chemistry and role of vadose zone in removal of nitrate and E. coli pollutants in Kolar District, Karnataka, India. Environmental Earth Sciences, 68(4), 927-938. doi:10.1007/s12665-012-1794-9.

Saatsaz, M., Sulaiman, W. N. A., Eslamian, S., \& Mohammadi, K. (2011). GIS DRASTIC model for groundwater vulnerability estimation of Astaneh-Kouchesfahan Plain, Northern Iran. International Journal of Water, 6(1/2), 1-14. doi:10.1504/IJW.2011.043313.

Sharifi, M., Hadidi, M., Vessali, E., Mosstafakhani, P., Taheri, K., Shahoie, S., \& Khodamoradpour, M. (2009). Integrating multi-criteria decision analysis for a GIS-based hazardous waste landfill sitting in Kurdistan Province, western Iran. Waste Management, 29(10), 2740-2758. doi:10.1016/j.wasman.2009.04.010. 
Shivendra, B. T., \& Ramaraju, H. K. (2015). Impact of onsite sanitation system on groundwater in different geological settings of Peri Urban Areas. Aquatic Procedia, 4, 1162-1172. doi:10.1016/j.aqpro.2015.02.148.

Singhai, A., Das, S., Kadam, A. K., Shukla, J. P., Bundela, D. S., \& Kalashetty, M. (2019). GIS-based multi-criteria approach for identification of rainwater harvesting zones in upper Betwa sub-basin of Madhya Pradesh, India. Environment, Development and Sustainability, 21(2), 777-797. doi:10.1007/s10668-017-0060-4.

Sugianti, K., Mulyadi, D., \& Maria, R. (2016). Analisis kerentanan pencemaran air tanah dengan pendekatan metode drastic di Bandung Selatan. Jurnal Lingkungan Dan Bencana Geologi, 71), 19-33. doi:10.34126/jlbg.v7i1.91.

Sumathi, V. ., Natesan, U., \& Sarkar, C. (2008). GIS-based approach for optimized siting of municipal solid waste landfill. Waste Management, 28(11), 2146-2160. doi:10.1016/j.wasman.2007.09.032.

Taryana, D. (2015). Pengaruh formasi geologi terhadap potensi mata air di Kota Batu. Jurnal Pendidikan Geografi, 20(2), 9-19. doi:10.17977/um017v20i22015p009.

Tiwari, K., Goyal, R., \& Sarkar, A. (2018). GIS-based Methodology for Identification of Suitable Locations for Rainwater Harvesting Structures. Water Resources Management, 32(5), 1811-1825. doi:10.1007/s11269018-1905-9.

USAID. (2016). Saatnya sekarang! layanan lumpur tinja terjadwal. Jakarta. Retrieved from https://www.iuwashplus.or.id/cms/wp-content/uploads/2017/04/Saatnya-Sekarang-LLTT.pdf.

Widiatmono, B. R., Anugroho, F., Nurlaelih, E. E., Sulianto, A. A., \& Lusiana, N. (2017). Assesment of the impacts of land use on water quality of Brantas Upstream, Batu City, Indonesia. Journal of Environmental Engineering and Sustainable Technology, 4(1), 18-25. doi:10.21776/ub.jeest.2017.004.01.4.

Zghibi, A., Merzougui, A., Chenini, I., Ergaieg, K., Zouhri, L., \& Tarhouni, J. (2016). Groundwater vulnerability analysis of Tunisian coastal aquifer: An application of DRASTIC index method in GIS environment. Groundwater for Sustainable Development, 2-3(August-September), 169-181. doi:10.1016/j.gsd.2016.10.001. 